\title{
CONTRIBUTION OF SYAIKH MUHAMMAD MAHFUZH AL-TARMASI IN THE DEVELOPMENT OF INTELLECTUAL- SPIRITUAL PESANTREN IN INDONESIA IN THE 20TH CENTURY
}

\author{
Dzulkifli Hadi Imawan \\ Indonesian Islamic University \\ Email: dzulkifli.hadi.imawan@uii.ac.id
}

\begin{abstract}
This study will examine the contribution of Shaykh Muhammad Mahfuzh al-Tarmasi in the intellectual-spiritual development of Islamic boarding schools in Indonesia in the 20th century M. Shaykh Muhammad Mahfuzh al-Tarmasi who became one of the archipelago scholars who teach at the Haram Mosque was noted to have a major role in the development pesantren intellectual-spiritual in the archipelago in the 20th century AD Even though Indonesia at that time was still overshadowed by colonialism, but through its guidance to students in Mecca made a major contribution in improving the intellectual-spiritual boarding schools in the archipelago so that Indonesia was free from colonialism. Therefore, this research becomes important to know how the contribution of Shaykh Muhammad Mahfuzh al-Tarmasi in the intellectual-spiritual development in Indonesian pesantren in the 20 th century $A D$. This study is a qualitative research with a historical approach. The results of this study stated that Shaykh Muhammad Mahfuzh al-Tarmasi contributed greatly to the development of the intellectual-spiritual boarding schools in Indonesia through his teaching to Indonesian students studying at the Haram Mosque and intensive coaching that combined fikriyah and ruhiyah to his students.
\end{abstract}

Keywords: Shaykh Muhammad Mahfuzh al-Tarmasi; Pesantren; Intellectual-Spiritual

\section{Preliminary}

The history of the development of Islam in the archipelago has attracted the attention of scholars from both western and Middle Eastern countries, from then until now. From the west represented by Tome Pires, Snouck Hurgronje, Martin van Bruinessen, Peter Carey, Mc Riklefs, HJ De Graff, Thomas Stamford Raffles, Denys Lombard and other western researchers have written extensively on the Islamic history of the archipelago. While from Middle Eastern researchers more biographies of influential archipelago figures in Makkah and the Arabian Peninsula as written by Umar Abdul Jabbar, Khairuddin Zirikly, al-Kattani, Ahmad Sibai, Said Mamduh al-Mishri, Abdullah Mu'allimi, Ali Thanthawi, Husain Mu'nis, Ismail Yaghi, Mahmud Syakir to the most classical ones such as Ibn Bathuthah who recorded the 
history of the archipelago in the 14th century AD (Abdul Jabbar, 1997); (Al-Kattani, tt); (Bruinessen, 2012); (Hurgronje, 1419); (Pires, 2016); (Raffles, 2014).

From these researchers, especially Arabic researchers, recorded in their books the archipelago scholars who they consider to be influential people in the world by having many works printed in various countries as well as students who become large and scattered scholars to teach their knowledge in various places in the world; starting from Mecca, Medina, Syria, Egypt, Tunisia, Morocco, Mauritinia, India, Malaysia, Thailand and Indonesia. Among the noted archipelago scholars is Shaykh Muhammad Mahfuzh bin Abdullah bin Abdul Mannan al-Tarmasi, who came from Tremas, a village in Pacitan, East Java. In the 20th century AD Shaykh Muhammad Mahfuzh al-Tarmasi was an influential ulama of the archipelago in Haramain. He is known as an expert in various scientific disciplines such as qiraat, tafsir, usul, fiqh, hadith, also tasawwuf and succeeded in writing 18 books in various disciplines. In Baabu as-Shafa Haram Mosque which is the place of halaqah teaching is always filled with students from various countries, especially students of the archipelago (Abdul Jabbar, 1997); (al-Mar'asyali, 2006); (al-Mu'allimi, 2000); (Al-Zirikli, 2002).

If Indonesia in the 20th century AD was still in the Dutch colonialism which had been going on since the 19th century AD, (Suryanegara, 2012) then Makkah during the time of Shaykh Mahfuzh al-Tarmasi was a safe and conducive place for learning science- religious knowledge with 120 halaqah in the Grand Mosque. So this makes it possible for students who are in Makkah to exchange information about the state of their respective countries at that time. (Al-Mazm, $1428 \mathrm{H}$ )

For this reason, the meeting of the archipelago students with Shaykh Mahfuzh al-Tarmasi in Makkah became an effective means of arousing the spirit of 'hubbul wathon' nationalism so that they would later try to change the state of Indonesia for the better. Moreover, these students are the sons of Islamic boarding school clerics in the archipelago so it is appropriate that al-Tarmasi conducts intensive training for them while in Makkah al-Mukarramah. Because it reflects on the battles of Muslims in the 19th century AD which always failed when dealing with the Dutch; as in the Javanese War led by Pangeran Diponegoro in 1825-1830 AD, also the Padri War led by Tuanku Imam Bonjol in the 1830-35, and the failure 
of the Muslims in the Banten peasant uprising in $1818 \mathrm{AD}$, then efforts to resist the invaders must change from battlefield to the pesantren field; namely teaching science to the people of Indonesia in order to have broad insights in looking and managing a brighter future. From this background, a further paper study will discuss how Shaykh Muhammad Mahfuzh al-Tarmasi played a role in the intellectual-spiritual development of pesantren (boarding school) in Indonesia in the 20th century AD.

\section{Shaykh Muhammad Mahfuzh al-Tarmasi; The Supreme Master of Ulama Nusantara in Makkah of the 20th Century AD}

Shaykh Muhammad Mahfuzh al-Tarmasi (1868-1920 AD) was the son of Kyai Abdullah, the caregiver of the Pesantren Tremas, Pacitan. While his grandfather named Kyai Abdul Mannan or Mas Bagus Sudarso were students of Kyai Ageng Hasan Besari Tegalsari and students of Shaykh Abdusshamad al-Falimbani; scholars who came from Palembang and became one of the teachers at the Haram Mosque in the eighteenth century (XVII AD) (Imawan, 2018b). He was born in Tremas, Pacitan, East Java so that by Arab historians he is known by the name alTarmasi or al-Turmusi, al-Jawi. He was also given the title of al-Makiy because he remained in Mecca until the end of his life in 1338 H/1920 AD, and was buried in Ma'la, camp near the Haram Mosque, Makkah al-Mukarramah. (Al-Falimbani, 1988; Al- Tarmasi, tt-c, tt-a).

Shaykh Mahfuzh since childhood has been educated by his own father Kyai Abdullah. And after that he studied with Kyai Salih Darat Semarang (d. 1903 AD) and the kyai in Jaw. He then studied the scholars of the Arabian Peninsula, Mecca and Medina such as Sayyid Abu Bakar Syatha (expert on fiqh and hadith, d. 1893 AD), Shaykh Muhammad Syinwani (expert in the Qur'an, d. 1897 AD), Shaykh Umar Barakat al. -Sami (d.1896 AD), Shaykh Musthafa Sulaiman al-'Afifi (ushul fiqh expert, d. 1891 AD), Sayyid Husain Muhammad al-Habsh (expert of hadith, d. 1912 AD), Shaykh Muhammad Said Babshil al-Hadrami (Mufti Madzhab Syafii at Makkah at that time, w.1912 AD), Shaykh Sarbini Dimyathi (qira'ah science expert, w.1904 AD), Sayyid Muhammad Amin al-Madani (hadith expert, 1911 AD), Sayyid Ahmad Zawawi al-Maliki (aqidah science expert, w.19999 AD), and other great scholars (Al-Tarmasi, tt-c). 
According to Shaykh Yasin al-Fadani in rawqiq Kifayah al-Mustafid, Patience and sincerity of Shaykh Mahfuzh in studying religion with little sleep and many staying up late to study and memorize made him a person who mastered many sciences such as hadith, fiqh, ushul, qiraah, and other sciences. And this led him to become one of the archipelago scholars who managed to get a noble position to teach at the Grand Mosque, precisely in Bab as-Shafa. (Al-Tarmasi, t.t.-c).

Interestingly, in Zirikly's note, Shaykh Mahfuzh was a prolific scholar of writers. He recorded three books namely Manhaj Dzawi al-Nazhar fi Syarh Manzhumah 'Ilmi al-Atsar li Imam Suyuthi (the science of hadith), Mauhibah dzi alFadl' al Syarh Muqaddimah Bafadl (4 volumes in the science of Shafi'i), and Ta'mim al-Fadl 'al Syarh Muqaddimah Bafadl (4 volumes in the science of Shafi'i), and Ta'mim al-Fadl -Manafi 'bi Qira'ah al-Imam Nafi' ang was written in 1324 H / 1907 AD (Al-Zirikli, 2002).

The note was added by Ilyas Barmawi in Imta'u al-Fudlala 'bi Tarajim alQurra', which included five other books of Shaykh Mahfuzh namely Nail al-Ma'mul Hasyiyah Ghayah al-Wushul 'ala Lubbi al-Usul, As' afu al-Mathali 'bi Syarhi al-Badr al-Lami' Nzhum Jam'i Jawami ', Hasyiyah Takmilati al-Manhaj al-Qawim, Ghunyah al-Thalabah bi Syarhi al-Thayyibah fi al-Qira'at al-'Asyar, Kifayah al-Mustafid li ma 'ala min al-Asanid. (al-Barmawi, 2000).

And in the notes of Umar Abdul Jabbar, it is mentioned that other books of Shaykh Mahfuzh such as al-Siqayah al-Mardliyah fi Asami Kutubi Ashabina alSyafi'iyah, al-Badru al-Munir fi Qira'ah al-Imam Ibn Kathir, Insyirah al -Fawaid fi Qira'ah al-Imam Hamzah, al-Minhah al-Khairiyyah, and al-Khil'ah al-Fikriyah bi Syarh al-Minhah al-Khairiyah (a book that reviews 40 hadiths). (Abdul Jabbar, 1997) Also mentioned by al-Kattani in Fahras al-Faharis, among the books of Shaykh Mahfuzh is al-Risala al-Tarmasiyah fi Isnad al-Qira'at al-'Asyariyah (once printed in Mecca in $1330 \mathrm{H} / 1912 \mathrm{AD}$ in 8 pages. (8 pages) Al-Kattani, tt) Also 'Inayah al-Muftaqir fi ma Yata'allaqu bi Sayyidina al-Khidr' alaihi al-salam and Bughyah al-Adzkiya fi al-Bahtsi 'an Karamat al-Awliya', Tahiatu al-Fikar bi Syarh Alfiyah al-Siyar which is the last book he finished writing on 18 Rabiul Awwal 1337 H / 1920 AD, or a month before he died in Mecca (Al-Tarmasi, 2011; Al-Tarmasiy, 2008). 
These books explain the expertise and depth of the science of Shaykh Mahfuzh al-Tarmasi in Islam. moreover the works are explained in various scientific fields; fiqh, ushul fiqh, qiraat, tafsir, hadith, to tasawwuf written by ilmiyah and referring to the mu'tabar scholars in each field. and perhaps the motivation for writing is as Shaykh Mahfuz al-Tarmasi noted in Hasyiyah alTarmasi by quoting from Ibn Subki, that writing is one effective way to spread benefits because the writing lasts for a long time. So it is not surprising that many students come to him to explore the Islamic religious sciences. (Al-Tarmasi, 2011).

Contributions of Shaykh Muhammad Mahfuzh al-Tarmasi in the Intellectual-

\section{Spiritual Development of the 20th Century Islamic Boarding School}

The contribution of Shaykh Mahfuzh al-Tarmasi in the intellectual-spiritual development of pesantren in the 20th century AD was enormous. Although he was not in the archipelago at the time, his teaching in the Islamic religious sciences to students, especially those from the archipelago in Makkah al-Mukarramah at that time was very influential in opening wider horizons and also raising awareness of hubbul wathan; love the motherland in themselves. Especially in Mecca at that time as noted by Siba'i, was experiencing rapid population growth due to the world war that caused many people to find a safe place like Makkah (Siba'i, 1419). Coupled with the opening of the Suez Canal and the operation of the ship fire, the archipelago made it easier for pilgrims to Makkah as Bruinessen noted, each year from 1855 to 1931 AD always increased to reach 10000 pilgrims in the archipelago in Makkah (Bruinessen, 2012).

At that time, especially when Shaykh Mahfuzh taught Islamic sciences by occupying one of the 120 halaqas in the Grand Mosque, precisely in the Chapter of Shafa; the nearest door to the hill of Shafa which is used to do sa'i, many students of the archipelago sit in a circle around it to study science. According to Amal Ramadan notes, in general in each of these halaqahs, clever students sit closest to their shaykh and halaqah for adult students starts at duha to duh and then continues until asar. There is also a halaqah between maghrib and isya which then continues for the next two hours (Ramadan, 2006).

As Umar Abdul Jabbar noted in Siyar wa Tarajim, the effort of Shaykh Mahfuzh al-Tarmasi to become a teacher at the Haram Mosque at that time was not 
easy, not just anyone except the teachers who succeeded in obtaining a teaching certificate at the Haram Mosque through a series of examinations led by by the council of scholars of the Grand Mosque (haiah al-'ulama) with material consisting of interpretations, hadith, fiqh, Arabic rules (qawaid al-lughah). After being declared graduated and entitled to become teachers at the Haram Mosque, they teach sincerely only expect the reward and pleasure of Allah Almighty because they can teach the religious sciences that are mandated for them at the Haram Mosque, they do not expect government salaries and also do not expect donations from Sadaqah students who study with them, even they have a theme to students who study with them especially when they come to their homes. And this is as passed by Shaykh Muhammad Mahfuzh al-Tarmasi at that time who taught the books that he wrote himself like the book of Jurisprudence Mauhibah dzi al-Fadl, the book of usul al-fiqh al-Kawkab al-Sathi 'syarh Nuzhum Jam'I al-Jawami '. Also other scholars like Shaykh Muhammad Nawawi al-Bantani who taught his commentary, Mirah Labid in two thick volumes, Shaykh Mukhtaruddin Atharid alBughuri, Shaykh Muhammad Fathani, Shaykh Muhammad Nur Fathani, and also Shaykh Muhammad Ahyad Idris. Their teaching activities at the Haram Mosque are well documented by Umar Abdul Jabbar in Siyar wa Tarajim (Abdul Jabbar, 1997).

According to Imawan in the Da'wah Ulama Nusantara Road in Haramain, in the 20th century $\mathrm{AD}$, pilgrims who came from the Archipelago did not only perform the pilgrimage and umrah alone, moreover the journey was quite long and tiring, so their opportunity to be in Haramain was usually used for studying Islamic sciences to the scholars there, especially to the scholars of the archipelago who at that time many were teaching at the Haram Mosque. (Imawan, 2018a) Masjid Al Haram is a scholar who has thousands of students, especially from the archipelago, even reaching 4000 people if counted during his teaching at the Haram Mosque (Mas'ud, 2006).

And during that time, Shaykh Mahfuzh al-Tarmasi taught the Islamic religious sciences to his students as a whole, by integrating the teachings of Ahlussunnah wal Jama'ah Asya'irah-Maturidiyah, Syafii Schools in Sharia, and Sunni Sufism as he received from his teachers. like Sayyid Abu Bakar Syatha and others. And indeed at that time, Mecca and Medina were the gathering place for the four fiqh religious 
scholars; Hanafi, Maliki, Syafii and Hanbali, all of whom followed the Ahlussunnah wal Jama'ah creed in the creed. Although usually the Haramain Ulama Council is chaired by Hanafi Madhhab scholars, the majority of scholars in Haramain and the world are followers of the Syafii School.

As recorded in Kifayah al-Mustafid, the material of aqidah taught by Shaykh Mahfuzh al-Tarmasi to his students is usually directed from books such as Jawharah al-Tawhid by Shaykh Ibrahim al-Laqqani, Ummu al-Barahin by Shaykh Muhammad Yusuf Sanusi, also the books of Abu Ma'ali Juwaini; Imam alHaramain, Imam Ghazali, Imam Nawawi al-Damasyqi, Tajuddin Subki are wellknown defenders of the Aqeedah Ahlussunnah wal Jama'ah. As for jurisprudence, he taught his great work Hasyiyah al-Tarmasi al-Manhal al-'Amim bi Hasyiyah alManhaj al-Qawim which means 'abundant springs' written as an explanatory book of al-Manhaj al-Qawim written by Imam Ahmad ibn Muhammad ibn Muhammad ibn Ali Ibn Hajar al-Haytami (d. 974 H/1567 AD), student of Shaykh al-Islam Zakariya al-Ansari, author of the book Fathu al-Wahhb. (Al-Tarmasi, tt-c) (AlTarmasi, 2011).

The Book of Hasyiyah al-Tarmasi is a book of Shafi'i fiqh which is very thick and unique because it has three names. Initially as explained by Shaykh Mahfuzh al-Tarmasi in his muqaddimah, this book was given the name Mauhibah dzi al-Fadl 'ala Syarh al-'Allamah Ibn Hajar Muqaddimah Bafadl which means the gift of god that has the gift of' written as an explanation of the book Imam Ibn Hajar al'Allamah Ibn Hajar Muqaddimah Bafadl which means the gift of god that has the gift of 'written as an explanation of the book Imam Ibn Hajar al -Haytami who explained the book of Muqaddimah Bafadl; a concise book of fiqh in the Syafii School written by a 16th century Yemeni scholar Imam Abdullah bin Abdurrahman ibn Abu Bakr ibn Muhammad al-Hajj ibn Abdurrahman ibn Abdullah ibn Yahya ibn Qadli Ahmad ibn Muhammad ibn Fadl bin Muhammad ibn Abdul Karim Bafadl alQahthaniy al-Sa'di al-Madzhijiy al-Hadramiy al-Tarimi (d. 918 H/1513 AD) (AlTarmasi, 2011). Explained by Doctor Muhammad Abdurrahman al-Ahdal, Lecturer at Taif University, Saudi Arabia, that the book Hasyiah Al-Tarmasi is the widest book of discussion of the Shafi'i scholars today, written with full analysis, detailed 
explanations and accuracy so that the difficult matters to be explained are explained easily in this book in neat and orderly order .

Not only that, although this book is a fiqh book that usually explains about legal issues, this book also explains much Arabic science which is quoted directly from experts by referring to 'reference-references such as the book of al-Shihah Taj al-Lughah Ismail al-Jauhari, Tahdzib al-Lughah Abu Manshur al-Azhari, alQamus al-Mukhith by al-Fairuz Abadi, and not infrequently Shaykh Mahfuzh also inserted nazham-nazham of nahwu, sharf, balaghah to complete the explanation of his book. Besides that, the book of Hasyiyah al-Tarmasi is a book of fiqh which is explained in terms of the main argument; Alqur'an and the hadith of the Messenger of Allah that was concluded by Shaykh Mahfuzh each hadith by referring to the explanations of the experts in the hadith traditions such as Hafizh Zainuddin alIraqi (w.806 H/1404 AD), Ibn Mulaqqan al-Andalusi (w. 804 H/1402 AD), Ibn Hajar al-Asqalani (d. 852 H/1449 AD). moreover, Shaykh Mahfuzh in giving an explanation in his hasyiyah always affix the words of the scholars of fiqh and compare them with each other, by including the verses of nadzham fiqih which refers to the book of Ibn Ibn Wardiy, al-Ma'fuwat, Taysir al- Tahrir and others. Finally, Shaykh Mahfuzh in his hasyiyah always wrote biographies of Shafi'ite scholars listed in the book he was ruling by explaining their academic position, works, and important matters related to them (Al-Tarmasi, 2011).

And interestingly, in the teaching of Shaykh Mahfuzh al-Tarmasi in Makkah it cannot be separated from the tradition of pesantren in the Indonesian Archipelago. Even though he was scheduled to teach at the Haram Mosque, his home, not far from the Haram Mosque, became a 'pesantren' for his students who wanted to get additional lessons from him. Even Shaykh Yasin al-Fadani said that Shaykh Mahfuzh's house was never quiet and was always crowded with students who wanted to explore Islamic sciences to him (Al-Tarmasi, t.t.-c). And this "pesantren tradition" is one of the strengthened relations of Shaykh Mahfuzh al-Tarmasi with his students. Moreover, every time he teaches, Shaykh Mahfuzh is also still familiar with the system of reading 'Javanese pesantren' which combines Arabic and Javanese. and of course, the closeness opens up a discussion and question-and- 
answer space and the exchange of information which usually results in a treatise or a special book (Al-Tarmasi, t.t.-c).

More than that, the example of Shaykh Mahfuzh in teaching his students became a very valuable lesson and was very impressed in the hearts of his students. As Shaykh Yasin al-Fadani explained, even though Shaykh Mahfuzh alTarmasi was a great scholar, he was close to anyone, polite and never looked down on other people and people '. So with this example, it is not surprising that he became a magnet that many students visited to study science with him (AlTarmasi, t.t.-c).

The teaching of Shaykh Mahfuzh to his students, especially the students of the archipelago in Mecca succeeded in giving a big influence in transferring the Islamic religious sciences both fikriyah and ruhiyah. As explained by Sayyid Alawi Abbas Maliki, that the presence of Shaykh Mahfuzh al-Tarmasi and also other scholars of the Grand Mosque made a very large contribution in giving birth to the scholars who participated in preaching to teach the Islamic religious sciences to the whole community and guide them to achieve ultimate happiness (Abdul Jabbar, 1997).

And the same thing was also mentioned by $\mathrm{KH}$ Maimun Zubair in giving muqaddimah book 'Inayah al-Muftaqir, that Shaykh mahfuzh succeeded in fostering great scholars who also played an important role in teaching Islamic religious sciences in Indonesia. They then established Islamic boarding schools spread in various regions in Indonesia and they also participated in establishing the Nahdlatul Ulama organization. Shaykh Mahfuzh al-Tarmasi is like a big tree that rises high, and his students are like branches of the tree, or they are like tributaries from the springs of knowledge found in Makkah al-Mukarramah. See (Surah Ar-Ra'du: 17) (Al-Tarmasi, t.t.-b).

There are indeed many students of Shaykh Mahfuzh al-Tarmasi who come from various countries; from Yemen such as Shaykh Allamah Umar ibn Abu Bakr ibn Abdullah ibn Umar ibn Ali ibn Muhammad Bajunaid born 1270 H/1854 AD and died in 1354 H/1936 AD, also from Damascus, Syria such as Shaykh Ahmad ibn Abdullah ibn Muhammad ibn Muhammad Syihabuddin al-Mukhallilati (1943 AD), also from Chinguetti, Mauritania (syinqitth) such as Hafizh Muhammad Habib bin 
Abdullah bin Ahmad Mayakba Janki (d. 1944 AD), also from Lucknow, Uttar Pradesh, India (al-Luknawi) like Shaykh Muhammad Abdul Baqi ibn Ali ibn Muhammad Mu'in Ayyubi (d. 1945 AD). Also from Al-Maharas, Tunisia such as Shaykh Umar Hamdan (w.1368 H 1949 AD) who later like Shaykh Mahfuzh became lecturers at the Haram Mosque and one of his main students was Shaykh Muhammad Yasin al-Fadani, Musnid al-'Ashr an expert on hadith this century, the owner of many sanad and teachers of more than 700 scholars (Al-Fadani, 1405; AlTarmasi, 2011).

But his students who came from the archipelago who played a major role in the establishment of Islamic boarding schools in Indonesia were no less numerous, and it was they who connected the intellectual-spiritual sanad shaykhs of Mahfuzh al-Tarmasi to the scholars in the archipelago, such as $\mathrm{KH}$ Hasyim Asyari the founder of the Tebuireng Islamic Boarding School -Jombang, KH. Bisri Sansuri Pesantren Manba'ul Ma'arif Jombang, KH Abdul Wahhab Hasbullah Pesantren Bahrul Ulum Tambak-Jombang Pesantren, KH M Ilyas Naqiyyah Pesantren Jombang, KH Romli Tamim Pesantren Rejoso Peterongan, KH As'ad Syamsul 'Arifin founder of Pesantren Sukorejo, KH. Abdul Mun'im founder of the Pesantren Nurul Jadid Probolinggo, KH. Nawawi Pasuruan Sidoarjo pesantren, KH Imam Zarkasyi founder of Gontor Darussalam Pesantren, KH Muhammad Fakih bin Abdul Jabbar founder of Pesantren Maskumambang Gresik, KH Ihsan bin Muhammad Dahlan founder of Jampes Kediri boarding school, KH. Dimyathi boarding school Tremas Pacitan, Kyai Baidlawi founder of the Pesantren Wahdatu al-Thullab Lasem, KH Khalil; grandfather Gus Qayyum founder of An-Nur Lasem Islamic Boarding School, KH Ma'shum Ahmad founder of Al-Hidayah Islamic Boarding School, KH. Bisri Musthafa Pesantren Raudlatut Thalibin Rembang, KH. Arwani Pesantren Yanbu 'alQur'an Kudus, KH. Abdul Muhith Pesantren Tasywiqutthullab and Ma'ahid Kudus, KH. Munawwir Krapak Islamic Boarding School, KH Muhammad bin Muhammad Mahfuzh al-Tarmasi founder of the Bustan Pesantren 'Usyaqi al-Qur'an Demak, KH Abbas Buntet the successor to the Buntet-Cirebon Islamic Boarding School, KH. Abdul Halim founded Hayatul Qulub in Majalengka, KH. Zainal Mustafa Pesantren Sukamanah, Kh. Makmun Nawawi al-Baqiyat al-Shalihat Islamic boarding school in 
Cibarusa, KH. Mukhtar Thabrani Pesantren an-Nur in Bekasi and many others. (Imawan, 2018a).

The pesantren became a place of religious study by their students who received the same teachings as Shaykh Mahfuzh al-Tarmasi taught them; integrate the creed of Ahlussunnah wal Jama'ah, Syafii School and tasawwuf. Even this was explicitly stated by KH Hasyim Asy'ari who stated that the Aqeedah Ahlussunnah wal Jama'ah, Syafii School, and also Sunni Sufism are characteristic of Islam in Indonesia which became the intellectual-spiritual heritage of the archipelago scholars (Asy'ari, tt)

And as time goes by, the pesantren are developing and giving birth to more pesantren, even today there are more than 28,000 pesantren in Indonesia (Dhofier, 2015) and these pesantren increasingly emphasize that the intellectual-spiritual development of pesantren in the 20th century AD cannot be separated from the influence of Shaykh Mahfuzh al-Tarmasi who became the great teacher and guide of fikriyah and ruhiyah who became the spirit of pesantren in Indonesia.

These pesantren are strong fortifications in maintaining the morals and creeds of Ahlu al-Sunah wa al-Jama'ah and Syafi'i Schools in the Archipelago. More than that, the pesantren also functions as a center for the study of Islamic sciences (tafaqquh fi al-din), a center for the procurement of ulama reproduction, a center for preserving tradition, Islamic culture, a center for da'wah and Islamic development. Through these pesantren, the Nusantara community is educated and physically, mentally and mentally nurtured, so that they become qualified, intellectual, faithful, and moral students and have high spiritual values. So it is not surprising if from the beginning until now the pesantren alumni have become movers and leaders or big figures in the archipelago.

\section{Conclusion}

Shaykh Muhammad Mahfuzh al-Tarmasi is an Indonesian scholar who became one of the influential scholars in Makkah al-Mukarramah in the 20th century AD. He who taught at Bab Shafa in the Grand Mosque was always crowded with students from various countries of the world to study the sciences Islam to him because he is known as a great scholar who specializes in various scientific 
fields; Jurisprudence, Usul, Hadith, Interpretation, Qiraah to Sufism and has many writings that he taught on the halaqah.

And through his teaching at the Grand Mosque he played a major role in the intellectual-spiritual development of pesantren in Indonesia in the 20th century $\mathrm{AD}$, namely through the teaching and coaching that he did to his students, especially those from the Indonesian archipelago. In addition, the example he set as an example was very memorable and made an impression on the hearts of his students so this was what they then followed when they returned to the archipelago and established boarding schools in their respective regions. The integrity of the creed of Ahlussunnah wal Jama'ah, Syafii School of Sharia and Sunni tasawwuf became a characteristic of the intellectual-spiritual boarding schools of Indonesia at that time which were increasingly developing while maintaining these values, and these are all forms of the contribution of Shaykh Muhammad mahfuzh al-Tarmasi in the 20th century.

\section{Bibliography}

Abdul Jabbar, U. (1997). Siyar wa Tarajim ba'dli 'Ulamaina fi al-Qarni al-Rabi 'Asyar. Tihamah.

al-Barmawi, I. (2000). Imta'u al-Fudhala' bi Tarajim al-Qura' fi ma Ba'da al-Qarn alTsamin al-Hijri. Dar Nadwah.

al-Mazm, A. (1428). Dirasah wa Tahqiq Is'âf al-Mathâli' bi Syarh al-Badr al-Lâmi' Nudhum Jam'i al-Jawâmi' Ta'lîf al-'Allâmah Muhammad Mahfuzh al-Tarmasi. Jamiah Ummul Qura.

Al-Fadani, S. M. Y. bin M. I. (1405). Ithaf al-Ikhwan bi ikhtishar Mathmahi al-Wujdan fi Asanid Syaikh Umar Hamdan. Dar Bashair.

Al-Falimbani, M. (1988). Bulugh al-Amany (1 ed.). Dar Qutaibah.

Al-Kattani, A. H. (t.t.). Fahras al-Faharis wa al-Astbat wa Mu'jam al-Ma'ajim wa alMasyikhat wa al-Musalsalat (1982 ed.). Dar Gharb Islamy.

al-Mar'asyali, Y. (2006). Natsr al-Jawahir fi 'Ulama al-Qarn al-Rabi' 'Asyar (I). Dar Ma'rifah.

al-Mu'allimi, A. (2000). A'lam Al-Makkiyin min al-Qarn al-Tasi' ila al-Qarn al-Rabi' Asyar al-Hijri. Muassasah al-Furqan. 
Al-Tarmasi, M. M. (t.t.-a). Al-Khil'ah al-Fikriyah. Fikrah.

Al-Tarmasi, M. M. (t.t.-b). 'Inayah al-Muftaqir fi ma Yata'allaqu bi Sayyidina al-Khidr 'alaihi al-salam. Fikrah.

Al-Tarmasi, M. M. (t.t.-c). Kifayah al-Mustafid li ma 'ala min al-Masanid. Fikrah.

Al-Tarmasi, M. M. (2011). Hasyiyah al-Tarmasi (I). Dar Minhaj.

Al-Tarmasiy, M. M. bin A. (2008). Bughyah al-Adhkiya' Fi al-Bahth An Karamat Al-awliya'. Kementerian Agama Republik Indonesia.

Al-Zirikli, K. (2002). Al-A'lam Qamus Tarajim li Asyhar al-Rijal wa al-Nisa' min al'Arab wa al-Musta'ribin wa al-Mustasyriqin (XV). Dar Ilmi li Malayin.

Asy'ari, K. M. H. (t.t.). Risalah ahli al-Sunnah wa al-Jama'ah. Maktabah Turats Islami.

Bruinessen, M. van. (2012). Kitab Kuning, Pesantren dan Tarekat. Gading Publishing.

Dhofier, Z. (2015). Tradisi Pesantren (Studi Pandangan Hidup Kyai dan Visinya Mengenai Masa Depan Indonesia) (IX). LP3ES.

Hurgronje, C. S. (1419). Shafahat min Tarikh Makkah al-Mukarramah. Dar Malik Abdul Aziz.

Imawan, D. H. (2018a). Jalan dakwah ulama Nusantara di Haramain abad 17-20 M.

Imawan, D. H. (2018b). The Intellectual Network of Shaykh Abdusshamad AlFalimbani and His Contribution in Grounding Islam in Indonesian Archipelago at 18th Century AD. Millah: Jurnal Studi Agama, 18(1), 31-50. https://doi.org/10.20885/millah.vol18.iss1.art3

Mas'ud, A. (2006). Dari Haramayn ke Nusantara Jejak Intelektual Arsitek Pesantren. Kencana Prenada Media Group.

Pires, T. (2016). Suma Oriental. Penerbit Ombak.

Raffles, Thomas. S. (2014). The History of Java (III). Narasi.

Ramadan, A. (2006). Al-Hayah al-'ilmiyah Fi Makkah (1115-1334 H/ 1703-1916 M). Jamiah Ummul Qura.

Siba'i, A. (1419). Tarikh Makkah Dirasat fi al-Siyasah wa al-'ilm wa al-ijtima" wa al'umran.

Suryanegara, A. M. (2012). Api Sejarah I (VII). Salam Madani. 
Contribution of Syaikh Muhammad Mahfuzh al-Tarmasi ... 